\title{
COMPARISON OF MICRO IRRIGATION SYSTEMS FOR OLIVE TREES
}

\author{
Nassar, A.
}

\begin{abstract}
Micro-Irrigation Systems (MIS) apply water through small devices which deliver it onto the soil surface very near to the plant, which means in this context the use of bubbler, mini-sprinkler and trickle irrigation systems. From 2003 to 2006, 13 feddans of field research were established in sandy soil at Wadi EL Natrown On-Farm Irrigation Department Research Station operated by the Water Management and Irrigation System Research Institute, to evaluate the effect of MIS on olive trees. The experimental site was arranged in a split plots design. On 08-02-2003 olive trees (Olea europaea L, Calamata cv.) were planted in the center of an irrigated round base of $1 \mathrm{~m}$ diameter. The distance between the tree rows and the trees within the same row are 5ms. Each plot was divided into six replicates giving 18 experimental plots.

All the micro irrigation systems were designed with the same control head components which consists of non- return valve, flow meter, venturi, air valve, pressure relief valve and 3 pressure gauges. Regarding the distributor units technical specifications and their placement: 1) For the trickle treatment 4 emitters $(12 \mathrm{l} / \mathrm{h})$ per each tree placed on one lateral line PE $16 \mathrm{~mm}$ diameter passing through the center of the tree round base; where each emitter is $30 \mathrm{~cm}$ distant from the next one; 2) For the bubbler treatment one bubbler per each tree $(100 \mathrm{l} / \mathrm{h})$ placed in the tree round base, $25 \mathrm{~cm}$ distance from the tree stem moving monthly in $180^{\circ}$ clockwise to maintain good water distribution; 3) For the mini-sprinkler treatment one mini-sprinkler $(70 \mathrm{l} / \mathrm{h})$ per each tree with the same procedure as the bubbler.

A comparison was made between the different systems taking into account the following points: olive trees morphology (plant height, stem diameter,

Water Management and Irrigation Systems Research Institute, National Water Research Center, Cairo, Egypt.
\end{abstract}


shoots number/tree, leaves number/tree, shadow area and root distribution), number of fruits/tree, fruit weight, yield/tree, total yield per feddan, yield efficiency and both soil moisture content and soil salt distribution. Hydraulics characteristics for each type of MIS were also monitored.

The results obtained show the usefulness of trickle irrigation system in olive trees growing where the trees height increased (cm) by 10 and $9.2 \%$, stem diameter ( $\mathrm{mm}$ ) increased by 6 and 14\%, shoots number per tree increased by 8 and $14 \%$, leaves number per tree increased by 13 and $17 \%$, shadow area $\left(\mathrm{cm}^{2}\right)$ increased by 6 and $13 \%$ compared with bubbler and micro irrigation system respectively.

Trickle irrigation systems demonstrate the highest values of sand soil moisture content which is about (18.19, 16.66 and $10.45 \%$ by weight) in the soil layers (00-30), (30-60) and (60-90) cm, respectively, whereas the bubbler irrigation systems were (16.66, 14.46 and $9.01 \%$ by weight) in the previous soil layers respectively, followed by mini-sprinkler irrigation systems treatment which were about (10.45, 9.01 and $6.58 \%$ by weight) in the same soil layers respectively. The olive trees root distribution under trickle irrigation showed more regularity than other types due to root distribution relative to the placement and the number of irrigation distributors.

The net effect of trickle-irrigation was to increase water saving for producing one kilogram of olive fruits with 18 and $35 \%$ less than with bubbler and mini-sprinkler respectively. The number of fruits increased under trickle irrigation by 16 to $24 \%$ while the olive tree yield ( $\mathrm{kg} /$ tree) increased by 18 to $32 \%$ compared with bubbler and mini sprinkler irrigation system respectively. Trickle-irrigation can be recommended as an efficient irrigation system for olive trees in the irrigation areas of Wadi El Natrown in the west of the delta region.

\section{INTRODUCTION}

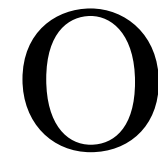
live (Olea europaea L.) is one of the most characteristic tree crops of the Mediterranean basin, where $98 \%$ of the land cultivated with lies within this region, where Spain, Italy and Turkey are the main producers. In Spain, the world's foremost olive- 
growing nation, the area devoted to this crop has increased by $27 \%$ over the last 20 years, while production has increased by 230\% (MAPA, 2004). This increase in productivity is mostly due to the micro irrigation of orchards. Olive is considered as one of the important fruit crops in Egypt. The total acre area grown with olive reached about 108322 feddans in 2000 out of which 73301 feddans are in fruit production, with a total production of about 281745 ton fruits. Around $30 \%$ of this area is grown in newly reclaimed lands. (El Khawaga, 2007).

Studies have shown that micro irrigation systems can increase olive production (Moriana et al., 2002) thereby increasing the total oil production per tree. However, studies differ regarding their overall performance to applied water. For example, Patumi et al. (2000) found that irrigation of olives increased yields substantially over those that were rain-fed.

The term "micro-irrigation system" (MIS) describes a family of irrigation systems that apply water through small devices which deliver water onto the soil surface very near to the plant or below the soil surface directly into the plant root zone.

Bucks and Davis (1986) listed a number of potential advantages for micro-irrigation. They include increased beneficial use of water, enhanced plant growth and yield, reduced salinity hazard, improved application of fertilizer and other chemicals, limited weed growth, decreased energy requirements, and improved cultural practices.

Many authors have proposed indicators to measure irrigation system performance as summarized by Rao (1993) and have given examples of their use at particular irrigation systems (Bos et al. 1994). Moreover, Assouline et al (2002) have given the reasons of reduction in water consumption with trickle systems of small portion of the soil volume to be due to decreased surface evaporation and reduction of water movement below the root zone. Sorensen et al (2001) and Clinton et al (2004) showed that the maximum yield requires a uniform moisture distribution and maintaining high and non fluctuated soil moisture within the root zone. Also, Ibrahim (1993), and Hassan (2002) reported that the methods of irrigation vary in this concern and lead to high or low irrigation efficiency. Irrigation methods and/or amount of applied water had a 
variable effect in salt distribution in the soil profile and mineral nutrients content [Ibrahim et al (1988 and 1993), Abd EL Samed (1995), Al Khateeb (1996), Goda (1998), Laz et al (1999), and Patumi et al (2000).

Charles (2005), found that there is salinity accumulation in the root zone of tree crops that have been irrigated with trickle or micro-spray irrigation systems located in arid and semi-arid regions.

The spatial distribution of the root system in the soil can determine the potential of a plant to exploit the soil's resources, which are unevenly distributed on earth's surface or subjected to localized depletion by the roots (Lynch, 1995). The production of a primary root system, i.e., the primary branching from the radical may have a major impact on growth and survival of a plant (Mac-Isaac et al., 1989). A primary root system increases the surface area available for the uptake of water and mineral elements. In addition, with its architecture, a primary root system provides physical support to the developing shoot.

In general, root development under trickle irrigation is constrained to the soil volume wetted by the emitters, near the soil surface with root length density decreasing with depth (Stevens and Douglas, 1994). However, recent studies have shown that root water uptake is not always in direct proportion.

The objectives of the present investigation were to study the effect of water methods i.e. trickles, bubbler and mini-sprinkler irrigation systems on growth, yield, yield efficiency and both moisture and salt distribution in the soil profile under olive trees.

\section{MATERIALS AND METHODS}

\subsection{Experimental Design}

This study was conducted on a 13 -feddans (one feddan equal $4200 \mathrm{~m}^{2}$ ) "field at Wadi El Natrown Experimental Station, On Farm Irrigation Department operated by Water Management and Irrigation Systems Research Institute". The Experimental Station is located at about $106 \mathrm{~km}$ North-West of Cairo in (N 30 $24^{-}$and E $30^{\circ} 30^{-}$). The field trial was 13 feddans divided into three treatments, the first 3 feddans are used to test the trickle irrigation system, the second 5 feddans are used to test mini- 
sprinkler irrigation systems and the third 5 feddans are used to test bubbler irrigation systems.

The experimental site was arranged in a split plots design. On 08-02-2003 olive trees (Olea europaea, Calamata $\underline{\mathrm{cv}}$.) one month age were planted in the center of an irrigated round base with $1 \mathrm{~m}$ diameter, 5 meters was the distance between the tree rows and 5 meters were the distance between the trees within the row. Each plot was divided into six replicates giving 18 experimental plots.

All the micro irrigation systems were designed with the same control head component, which consists of non- return valve, flow meter, venturi fertilizer, air valve, pressure relief valve, 3 pressure gauges. The distributor unit technical specifications and their placement are as follows:

1) Regarding the trickle treatment 4 emitters $(12 \mathrm{l} / \mathrm{h}$ at pressure operating 1 bar ) per each tree placed on one lateral line PE 16 $\mathrm{mm}$ diameter passing through the center of the tree round base, where each emitter is $30 \mathrm{~cm}$ away from the next one and $15 \mathrm{~cm}$ from the olive tree stem.

2) Regarding the bubbler treatment one bubbler per each tree (100 $1 / \mathrm{h}$ at pressure operating $1 \mathrm{bar}$ ) placed in the tree round base , 50 $\mathrm{cm}$ away from the tree stem and moving monthly in $180^{\circ}$ clockwise to maintain good water distribution;

3) Regarding the mini- sprinkler treatment one mini-sprinkler (70 l/h at pressure operating 1 bar) with $1.2 \mathrm{~m}$ as wetted diameter for each tree with the same procedure as the bubbler.

Irrigation water and some soil physical and chemical properties were analyzed and recorded in table (1) according to the standard methods APHA (1989) and Peterson and Calvin (1965).

Climate data were measured at a weather station adjacent to the field. The irrigation water was applied according to the tree requirements and shortage of the soil moisture content, in order to raise the moisture content of the soil to its field capacity. Soil moisture samples were determined gravimetrically and calculated on dry weight following Garcia (1978). The amount or the depth of irrigation water was calculated according to the equation given by Israelsen and Hansen (1962). 
Each micro irrigation system applied the same amount of irrigation water which is shown in table (2) as based on the average of the three studied seasons. For measuring the amount of irrigation water applied, a flow meter was used with each micro irrigation system. The tested trees received the usual agricultural treatments as followed by the olive orchards management.

\section{3-1 The Studied Parameters}

\section{3-1-1. Morphological Characters of Olive Trees}

Selected samples of olive trees from each MIS were taken at the end of the growing season (October) to measure the trees height $(\mathrm{cm})$, stem diameter $(\mathrm{mm})$, shoots number per tree, leaves number per tree and shadow area $\left(\mathrm{cm}^{2}\right)$.

\section{3-1-2 Root Distribution of Olive Trees}

Under different treatments, the olive trees were visually examined to measure root proliferation in horizontal and vertical direction. A rooting pattern examination was carried out through trenches of one-meter length, one meter wide and approximately $75 \mathrm{~cm}$ deep. A side wall of the trenches was carefully excavated to keep the root distribution pattern without damage. A semi-quantitative estimation was carried out according to Bohm, 1979.

Table (1): Some soil and irrigation water characteristics.

\begin{tabular}{|c|c|c|c|c|c|c|c|c|c|c|c|}
\hline \multirow{2}{*}{$\begin{array}{l}\text { Soil } \\
\text { depth }\end{array}$} & \multicolumn{11}{|c|}{ Soil physical properties (\%) } \\
\hline & Sand & Silt & Clay & \multicolumn{3}{|c|}{ Soil Texture } & F.C & \multicolumn{2}{|c|}{ W.P } & \multicolumn{2}{|c|}{$\mathrm{Bd}\left(\mathrm{gm} / \mathrm{cm}^{3}\right)$} \\
\hline $00-30$ & 94.5 & 3.5 & 2.0 & \multicolumn{3}{|c|}{ Sand } & 15.0 & 5.5 & 9.5 & \multicolumn{2}{|c|}{1.65} \\
\hline $30-60$ & 95.7 & 3.0 & 1.3 & \multicolumn{3}{|c|}{ Sand } & 16.7 & 4.3 & 12.4 & \multicolumn{2}{|l|}{1.44} \\
\hline $60-90$ & 97.0 & 2.0 & 1.0 & \multicolumn{3}{|c|}{ Sand } & 18.5 & 3.9 & 14.6 & \multicolumn{2}{|l|}{1.30} \\
\hline \multicolumn{12}{|c|}{ Soil chemical properties } \\
\hline $\begin{array}{l}\text { Soil } \\
\text { depth }\end{array}$ & $\begin{array}{c}\mathrm{EC} \\
(\mathrm{dS} / \mathrm{m})\end{array}$ & $\mathrm{CO}_{3}^{--}$ & $\begin{array}{l}\mathrm{HC} \\
\mathrm{O}_{3}^{-}\end{array}$ & \multicolumn{2}{|c|}{$\mathrm{CL}^{-}$} & $\mathrm{SO}_{4}^{--}$ & $\mathrm{Ca}^{++}$ & $\mathrm{Mg}^{++}$ & $\mathrm{Na}^{+}$ & $\mathrm{K}^{+}$ & SAR \\
\hline $00-30$ & 1.25 & & 0.93 & \multicolumn{2}{|c|}{1.98} & \multicolumn{2}{|c|}{9.61} & 6.33 & 3.44 & 0.51 & 1.66 \\
\hline $30-60$ & 1.36 & & 1.33 & \multicolumn{2}{|c|}{2.11} & \multicolumn{2}{|c|}{10.16} & 2.29 & 3.91 & 0.65 & 1.84 \\
\hline $60-90$ & 2.15 & & 1.80 & \multicolumn{2}{|c|}{2.58} & 17.12 & & \multicolumn{2}{|c|}{3.67} & 0.72 & 1.54 \\
\hline \multicolumn{12}{|c|}{ Water chemical properties } \\
\hline $\begin{array}{l}\text { EC } \\
(\mathrm{dS} / \mathrm{m})\end{array}$ & $\mathrm{CO}_{3}^{--}$ & $\mathrm{HCO}$ & & $\mathrm{JL}^{-}$ & & & $\mathrm{Ca}^{++}$ & $\mathrm{Mg}^{++}$ & $\mathrm{Na}^{+}$ & $\mathrm{K}^{+}$ & SAR \\
\hline 1.1 & 0.00 & 4.48 & & .00 & & & 2.98 & 1.87 & 5.65 & 0.50 & 3.63 \\
\hline
\end{tabular}

$\mathrm{FC}=$ Field Capacity; $\mathrm{WP}=$ Wilting Point; $\mathrm{A} . \mathrm{W}=$ Available Water; $\mathrm{Bd}=$ Bulk density 
Table (2): Average amount of water applied $\left(\mathrm{m}^{3} / \mathrm{fed}\right.$ and $\mathrm{m}^{3} /$ tree) during one growing year.

\begin{tabular}{|l|c|c|}
\hline \multirow{2}{*}{ Months } & \multicolumn{2}{|c|}{ Amount of Water applied } \\
\cline { 2 - 3 } & $\left(\mathbf{m}^{\mathbf{3} / \mathbf{f e d})}\right.$ & 0.23 \\
\hline January & 38.64 & 0.44 \\
\hline February & 73.92 & 0.69 \\
\hline March & 115.92 & 0.93 \\
\hline April & 156.24 & 1.22 \\
\hline May & 204.96 & 1.42 \\
\hline June & 238.56 & 1.55 \\
\hline July & 260.40 & 1.59 \\
\hline August & 267.12 & 0.71 \\
\hline September & 119.28 & 0.55 \\
\hline October & 92.40 & 0.42 \\
\hline November & 70.56 & 0.36 \\
\hline December & 60.48 & 10.11 \\
\hline Total amount of water applied & 1698.48 & \\
\hline
\end{tabular}

\section{3-1-3 Olive Yield}

In the selected olive trees samples, the number of fruits/tree, fruit weight $(\mathrm{gm})$, yield ( $\mathrm{kg} /$ tree) were determined at proper maturity to calculate the total yield per feddan.

\section{3-1-4 Yield Efficiency (Y.E)}

It was calculated according to the equation described by Ibrahim et al (1988) as follows:

$$
\text { Y.E. }=\frac{\text { Water applied }\left(\mathrm{m}^{3} / \mathrm{fed}\right)}{\text { Yield }(\mathrm{kg} / \mathrm{fed})}=\mathrm{m}^{3} \text { water } / \mathrm{kg}
$$

\section{3-1-5 Soil Moisture and Salt Distribution}

Soil samples were taken around the tree, $25 \mathrm{~cm}$ as distance from the tree stem and 24 hours after irrigation at three successive soil depths (00 - 30), (30 - 60) and $(60-90) \mathrm{cm}$ for each studied micro irrigation system treatment to obtain the average percentage of soil moisture.

The salt distribution was determined as electrical conductivity which was measured in 1:1 water soil extract of the soil samples taken around the tree for three successive soil depths (00-30), (30-60) and (60$90) \mathrm{cm}$ for each studied micro irrigation system treatment. 


\section{3-2 Statistical Analysis}

The obtained data were subject to the standard analysis of variance procedure. Values of L.S.D. were obtained whenever the calculated "F" values were significant at 5\% and $1 \%$ levels. (Snedecor and Cochran 1980).

\section{RESULTS and DISCUSSOIN}

\section{4-1. Morphological Characteristics of Olive Trees}

Morphological characteristics of olive trees are very sensitive parameters as, they directly affect the quality and quantity of olive yield. The type of MIS which has a direct higher affect on morphological characteristics will lead to directly high yield.

Results presented in table (3) and figure (1) show the main values of morphological characteristics such as trees height $(\mathrm{cm})$, stem diameter $(\mathrm{mm})$, shoots number per tree, leaves number per tree and shadow area $\left(\mathrm{cm}^{2}\right)$ as affected by irrigation application during the three seasons of study. It is obvious from the results that all morphological characteristics increased significantly when olive trees were subject to trickle irrigation system either in the first, the second or the third studied seasons and the reduction in all morphological characters were more pronounced with that irrigated with mini-sprinkler irrigation system compared with the other irrigation systems in the three studied seasons of growth. Moreover, the average of trees height $(113.85,160.63$ and $181.30 \mathrm{~cm})$, stem diameter (5.59, 6.48 and $8.53 \mathrm{~mm})$, shoots number per tree (3.56, 3.99 and 4.75), leaves number per tree $(399.98,431.06$ and 439.66) and shadow area $\left(92.76,125.88157 .93 \mathrm{~cm}^{2}\right)$ in 2004, 2005 and 2006 seasons respectively, were obtained when olive trees were irrigated by trickle irrigation systems.

The increase in all morphological characters by trickle irrigation systems might be attributed to the favorable effect of maintaining soil moisture at no stress for the growth of olive trees, minimizing the irrigation water losses, and maximizing the water application efficiency. 
Table (3): The effect of different MIS on average olive trees height $(\mathrm{cm})$ stem diameter $(\mathrm{mm})$, shoots number/tree and shadow area $\left(\mathrm{cm}^{2}\right)$ during 2004, 2005 and 2006 seasons.

\begin{tabular}{|c|c|c|c|c|c|c|}
\hline MIS & $\begin{array}{l}\text { Growing } \\
\text { seasons }\end{array}$ & $\begin{array}{c}\text { Trees } \\
\text { height } \\
\text { (cm) }\end{array}$ & $\begin{array}{c}\text { Stem } \\
\text { diameter } \\
(\mathbf{m m})\end{array}$ & $\begin{array}{l}\text { Shoots } \\
\text { number } \\
\text { per tree }\end{array}$ & $\begin{array}{l}\text { Leaves } \\
\text { number } \\
\text { per tree }\end{array}$ & $\begin{array}{c}\text { Shadow } \\
\text { area } \\
\left(\mathrm{cm}^{2}\right)\end{array}$ \\
\hline \multirow{4}{*}{ Trickle } & $2003-2004$ & 113.85 & 5.59 & 3.65 & 399.98 & 92.76 \\
\hline & 2004-2005 & 160.63 & 6.48 & 3.99 & 431.06 & 125.88 \\
\hline & 2005-2006 & 181.30 & 8.53 & 4.75 & 439.66 & 157.93 \\
\hline & Average & 155.26 & 6.87 & 4.13 & 423.57 & 125.52 \\
\hline \multirow{4}{*}{ Bubbler } & 2003-2004 & 110.10 & 5.33 & 3.47 & 337.98 & 87.51 \\
\hline & 2004-2005 & 140.35 & 6.09 & 3.68 & 365.19 & 123.88 \\
\hline & 2005-2006 & 173.20 & 7.91 & 4.18 & 394.95 & 141.17 \\
\hline & Average & 141.22 & 6.44 & 3.78 & 366.04 & 117.52 \\
\hline \multirow{4}{*}{$\begin{array}{r}\text { Mini- } \\
\text { Sprinkler }\end{array}$} & $2003-2004$ & 112.30 & 4.93 & 3.12 & 321.33 & 80.03 \\
\hline & 2004-2005 & 130.58 & 5.39 & 3.54 & 344.27 & 110.17 \\
\hline & 2005-2006 & 161.74 & 7.47 & 4.00 & 387.18 & 136.65 \\
\hline & Average & 128.54 & 5.93 & 3.55 & 350.93 & 108.95 \\
\hline \multicolumn{2}{|c|}{ "F" test } & $* *$ & $* *$ & $* *$ & $* *$ & $* *$ \\
\hline \multicolumn{2}{|c|}{ LSD of irrigation } & & & & & \\
\hline \multirow{2}{*}{\multicolumn{2}{|c|}{$\begin{array}{l}\text { systems at } 0.01 \\
\text { at } 0.05\end{array}$}} & 1.26 & 0.58 & 0.012 & 0.049 & 0.035 \\
\hline & & 0.83 & 0.38 & 0.008 & 0.032 & 0.023 \\
\hline \multirow{2}{*}{\multicolumn{2}{|c|}{$\begin{array}{l}\text { LSD of seasons } \\
\text { at } 0.01\end{array}$}} & & & & & \\
\hline & & 0.48 & 0.03 & 0.003 & 0.034 & 0.002 \\
\hline \multirow{2}{*}{\multicolumn{2}{|c|}{ at 0.05}} & 0.35 & 0.02 & 0.002 & 0.025 & 0.001 \\
\hline \multirow{3}{*}{\multicolumn{2}{|c|}{$\begin{array}{l}\text { at } 0.01 \\
\text { at } 0.05\end{array}$}} & & & & & \\
\hline & & 0.83 & 0.05 & 0.010 & 0.058 & 0.004 \\
\hline & & 0.60 & 0.02 & 0.004 & 0.042 & 0.003 \\
\hline
\end{tabular}

\subsection{Root Distribution of Olive Trees}

Studying the root pattern development and water uptake is especially important for the optimization of irrigation water use efficiency. Water should not be applied in areas where roots are absent, or at a rate higher than the roots can possibly take up.

Figures (2, 3 and 4) indicate that approximately $83 \%$ of the root distribution under MIS observed, approximately was located in the upper $30 \mathrm{cms}$ of the soil profile. This finding is in agreement with other studies of root distribution (San-Antonio, 1982; Hendrick and Pregitzer, 1996). 
It is also indicated that root development under MIS is constrained to the soil volume wetted by the water distributor, near the soil surface with root length density decreasing with depth (Goldberg et al., 1971; Stevens and Douglas, 1994; Michelakis et al., 1993).

So, it is clear that, the olive trees root distribution under trickle irrigation showed more regularity than other types due to root distribution relative to the placement and the number of irrigation distributors; many irrigation distributor points increased the wetted area more than one point for the same quantity of water. This root distribution regularity under trickle irrigation will have a positive effect on olive trees morphology and yield compared with bubbler and mini sprinkler irrigation systems.

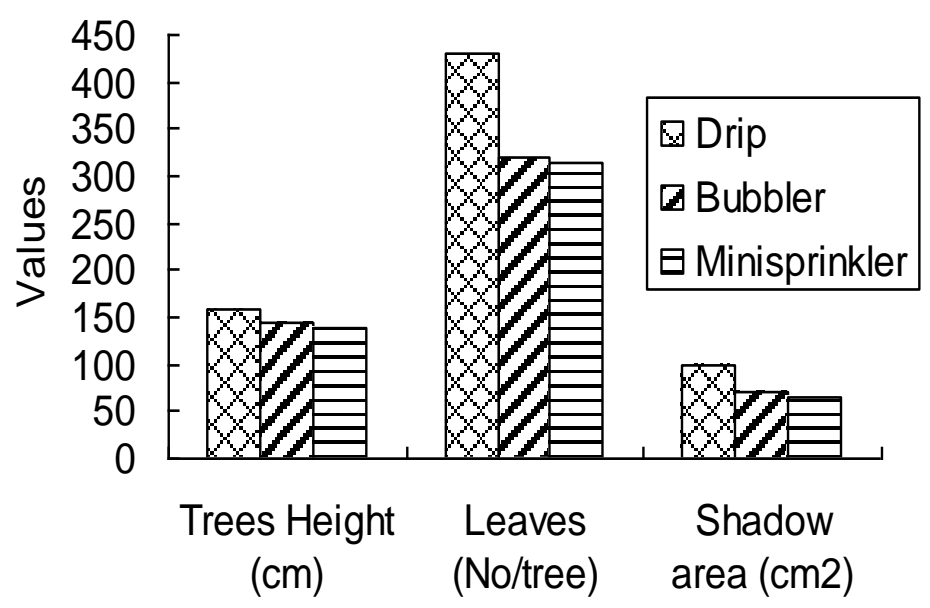

Fig (1): The effect of different MIS on some morphological characteristics of olive trees.

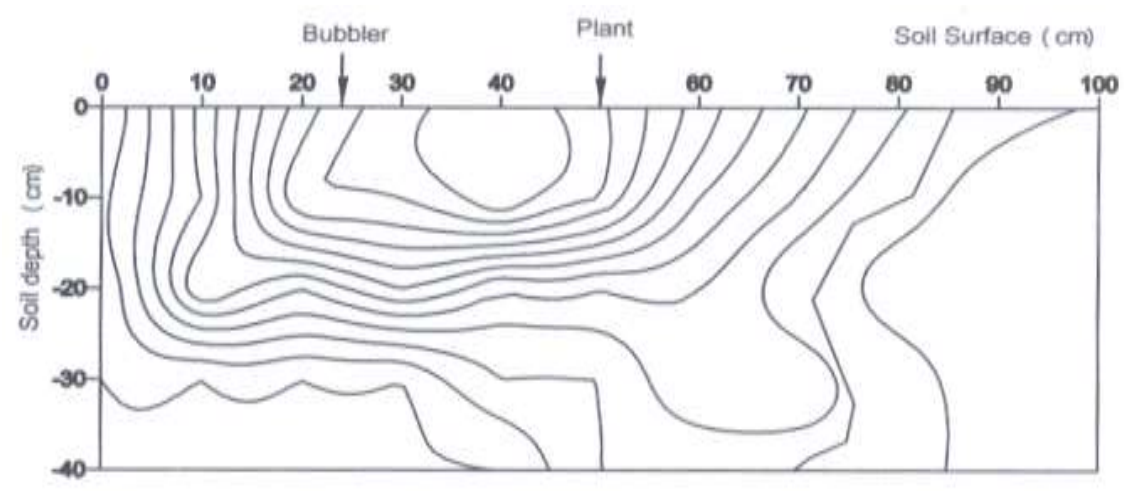

Fig (2): The effect of bubbler irrigation on olive root distribution. 


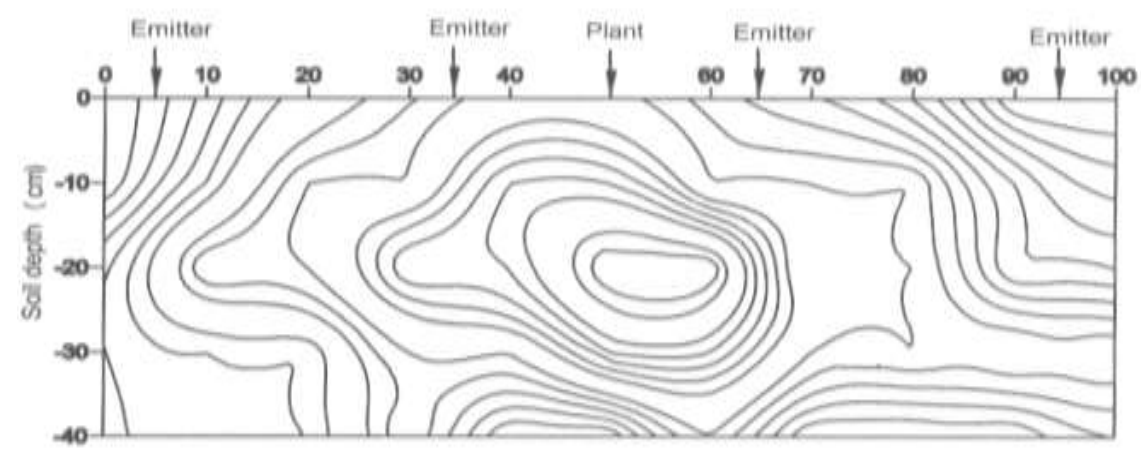

Fig (3): The effect of trickle irrigation on olive root distribution.

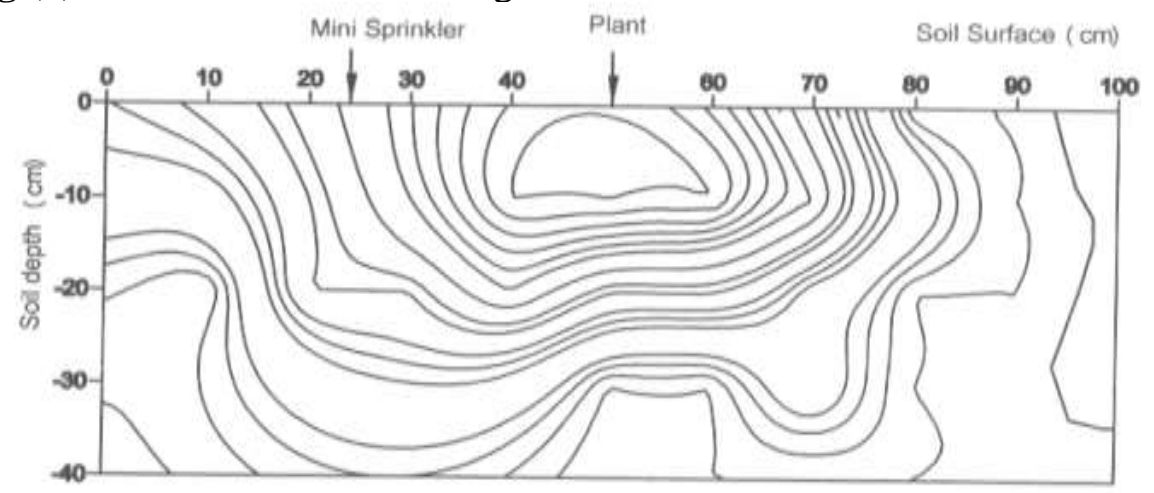

Fig (4): The effect of mini-sprinkler irrigation on olive root distribution.

\subsection{Olive Yield}

Table (4) and figure (5) show the average number of fruits/tree, fruit weight $(\mathrm{gm})$, yield $(\mathrm{kg} / \mathrm{tree})$ and total yield $(\mathrm{kg} / \mathrm{fed})$ for olive as affected by MIS based on the average of the three studied seasons.

It's clear that MIS had a significant effect on the number of fruits/trees, fruit weight $(\mathrm{gm})$, yield $(\mathrm{kg} / \mathrm{tree})$ and total yield $(\mathrm{kg} / \mathrm{fed})$ of olive considering average in the studied seasons. The number of fruits/tree is one of the parameters to be carefully considered, changes in this parameter will be directly reflected into the quantity and quality of the olive yield. Using trickle irrigation system increased the number of fruits per tree by 16 and $24 \%$ compared with bubbler and mini-sprinkler respectively. 
Table (4): The effect of different MIS on the average number of fruits/tree, fruit weight $(\mathrm{gm})$ yield $(\mathrm{kg} / \mathrm{tree})$, total yield $(\mathrm{kg} / \mathrm{fed})$ and yield efficiency $(\mathrm{kg} / \mathrm{fed})$.

\begin{tabular}{|c|c|c|c|c|c|}
\hline MIS & $\begin{array}{l}\text { Number of } \\
\text { fruits/tree }\end{array}$ & $\begin{array}{c}\text { Fruit } \\
\text { weight } \\
\text { (gm) }\end{array}$ & $\begin{array}{c}\text { Yield } \\
\text { (kg/tree) }\end{array}$ & $\begin{array}{c}\text { Total yield } \\
\text { (kg/fed) }\end{array}$ & $\begin{array}{l}\text { Yield } \\
\text { efficiency } \\
\left(\mathrm{m}^{3} / \mathbf{k g}\right)\end{array}$ \\
\hline Trickle & 22945.38 & 4.76 & 109.22 & 18348.96 & 0.09 \\
\hline Bubbler & 19355.60 & 4.64 & 89.81 & 15088.08 & 0.11 \\
\hline $\begin{array}{l}\text { Mini- } \\
\text { sprinkler }\end{array}$ & 17472.09 & 4.30 & 75.13 & 12621.84 & 0.14 \\
\hline "F" test & $* *$ & $* *$ & $* *$ & $* *$ & $* *$ \\
\hline LSD at 0.01 & 0.019 & 0.070 & 0.041 & 0.017 & 0.004 \\
\hline LSD at 0.05 & 0.013 & 0.049 & 0.028 & 0.011 & 0.003 \\
\hline
\end{tabular}

One of the parameters characterizing the quality of the olive fruits is the weight (gm), where the average of olive fruit weight was 4.76, 4.64 and $4.30 \mathrm{gm} /$ fruit under trickle, bubbler and mini-sprinkler respectively.

Concerning yield $(\mathrm{kg} / \mathrm{tree})$ and $(\mathrm{kg} / \mathrm{fed})$, the results indicated that the highest value was obtained under trickle irrigation $109.22 \mathrm{~kg} /$ tree, with 18 and $32 \%$ as an increment from bubbler and mini-sprinkler respectively. The same trend for olive yield per feddan under trickle irrigation obtained the highest value $18348.96 \mathrm{~kg} / \mathrm{fed}$, while the lowest $(12621.84 \mathrm{~kg} / \mathrm{fed})$ was obtained under mini-sprinkler irrigation system.

In general, the previous results lead to the conclusion that olive trees need enough irrigation water to keep the soil moisture at time of irrigation at the field capacity and good salt distribution in the soil layers.

Regarding yield efficiency (the amount of applied water per cubic meter that could produce one kilogram of olive fruits) as affected by MIS treatments the trickle irrigation system demonstrates more water saving for producing one kilogram of olive fruits with 18 and 35\% less than with bubbler and mini-sprinkler respectively. These results are in accordance with those reported by Rugiero (1991), Abd El Aziz (1998) and Emtithal (2002) stated that the amount of water and method of irrigation and application of it are important for determining the cropping potential for apricots and oranges.

From the previous discussion, it can be concluded that, the changes in yield under each studied MIS treatment are mainly due to the effect of water distribution method which leads to good water distribution and 
compensates for moisture depletion from the root zone in the correct time to avoid water stress on the growing trees.

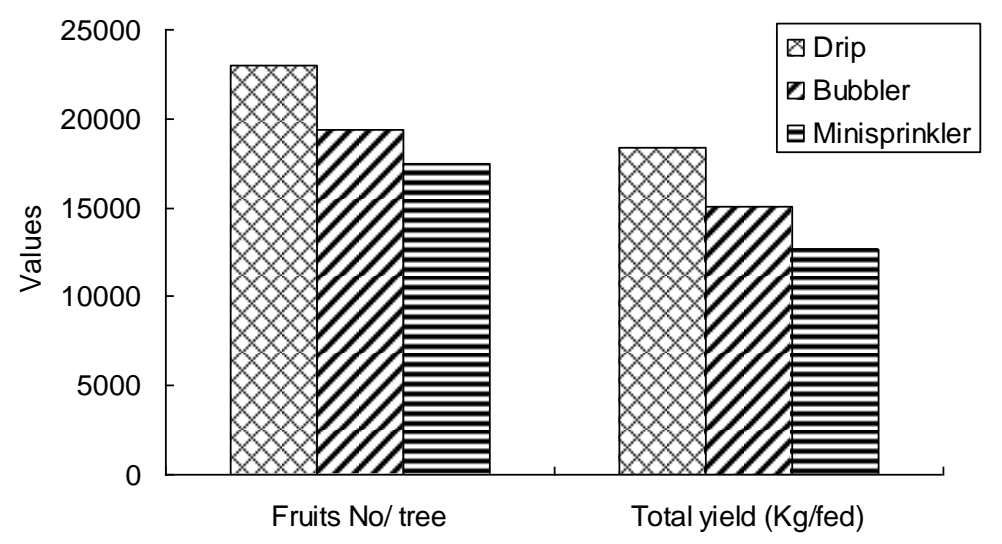

Figure (5): The effect of different MIS on olive yield.

\subsection{Soil Moisture and Salt Distribution}

This part of the study was concerned with the effect of different MIS irrigation systems on soil moisture and salt distribution in soils tested for olive trees cultivation (soil profile). This is done by determining the soil moisture content and the electrical conductivity of soil samples taken from different distances from the trunk of the tree and at three depths from the soil surface. The samples average results are presented in table (5) and illustrated in figure (6).

The results showed that the moisture content distribution pattern was greatly affected by the types of micro irrigation systems. The trickle irrigation system exhibited the highest moisture content compared with the other studied micro irrigation systems, where its moisture content ranged from about 18.19 to $16.66 \%$ by weight in the top (00-30) and (3060) $\mathrm{cm}$ layers. At more than $60 \mathrm{~cm}$ the soil moisture decreased and reached $10.45 \%$ by weight. For the bubbler irrigation system, the soil moisture content was $16.66 \%$ by weight in the top layer $(00-30) \mathrm{cm}$, while the deepest $(60-90) \mathrm{cm}$ layer had less moisture content than the field capacity. The mini-sprinkler irrigation system's moisture content ranged from 10.45 to $6.58 \%$ by weight which was less than the field capacity in the top $60 \mathrm{~cm}$ and which may be insufficient to meet the tree water demand at this period.

From the previous information, it could be concluded that the trickle irrigation system may give sufficient available water in the top layers (00$60) \mathrm{cm}$ where the trees consume most of their water demand followed by bubbler and mini-sprinkler irrigation systems treatments. 
Concerning the soluble salts distribution (EC dS/m), the data shown in table 5 and figure (7) revealed that the soil salinity was affected by the moisture distribution which was in turn governed by the studied three micro irrigation systems.

The soil salinity increased with the vertical distance from the emitter, bubbler or mini-sprinkler. The maximum values obtained under trickle irrigation was $(2.73 \mathrm{dS} / \mathrm{m})$ at the $(60-90) \mathrm{cm}$, while the maximum values of the salinity were obtained at the bottom layer of the wetted zone in both bubbler and mini-sprinkler irrigation systems treatment (3.34 and $3.68 \mathrm{dS} / \mathrm{m}$, respectively). In the mean time, the soil salinity in the main root zone was relatively low under the studied three micro irrigation systems.

These can lead to the conclusion that the olive tree growth and consequently yield production may not be greatly affected by the salinity but mainly by soil moisture distribution and availability.

Table (5): The effect of different MIS on soil moisture distribution (\% by weight) and soil salinity $(\mathrm{dS} / \mathrm{m})$ distribution pattern under olive trees.

\begin{tabular}{|c|c|c|c|}
\hline MIS & $\begin{array}{l}\text { Soil layers } \\
\text { depths }(\mathrm{cm})\end{array}$ & $\begin{array}{c}\text { Soil moisture } \\
\text { distribution } \\
\text { (\% by weight) }\end{array}$ & $\begin{array}{c}\text { Soil salinity distribution } \\
(\mathrm{dS} / \mathrm{m})\end{array}$ \\
\hline Trickle & $\begin{array}{l}00-30 \\
30-60 \\
60-90\end{array}$ & $\begin{array}{l}18.19 \\
16.66 \\
10.45\end{array}$ & $\begin{array}{l}0.79 \\
1.44 \\
2.73\end{array}$ \\
\hline Bubbler & $\begin{array}{l}00-30 \\
30-60 \\
60-90\end{array}$ & $\begin{array}{c}16.66 \\
14.46 \\
9.01\end{array}$ & $\begin{array}{l}0.88 \\
1.95 \\
3.34\end{array}$ \\
\hline Mini-sprinkler & $\begin{array}{l}00-30 \\
30-60 \\
60-90\end{array}$ & $\begin{array}{l}10.45 \\
9.01 \\
6.58\end{array}$ & $\begin{array}{l}0.93 \\
1.68 \\
3.68\end{array}$ \\
\hline \multicolumn{2}{|c|}{$\begin{array}{l}\text { LSD of irrigation systems at } 0.01 \\
\text { at } 0.05 \\
\text { LSD of s Soil layers depths at } 0.01 \\
\text { at } 0.05 \\
\text { LSD of interaction at } 0.01 \\
\text { at } 0.05\end{array}$} & $\begin{array}{c}* \\
0.028 \\
0.019 \\
0.029 \\
0.021 \\
0.050 \\
0.036\end{array}$ & $\begin{array}{c}* * \\
0.005 \\
0.004 \\
0.020 \\
0.015 \\
0.035 \\
0.026\end{array}$ \\
\hline
\end{tabular}




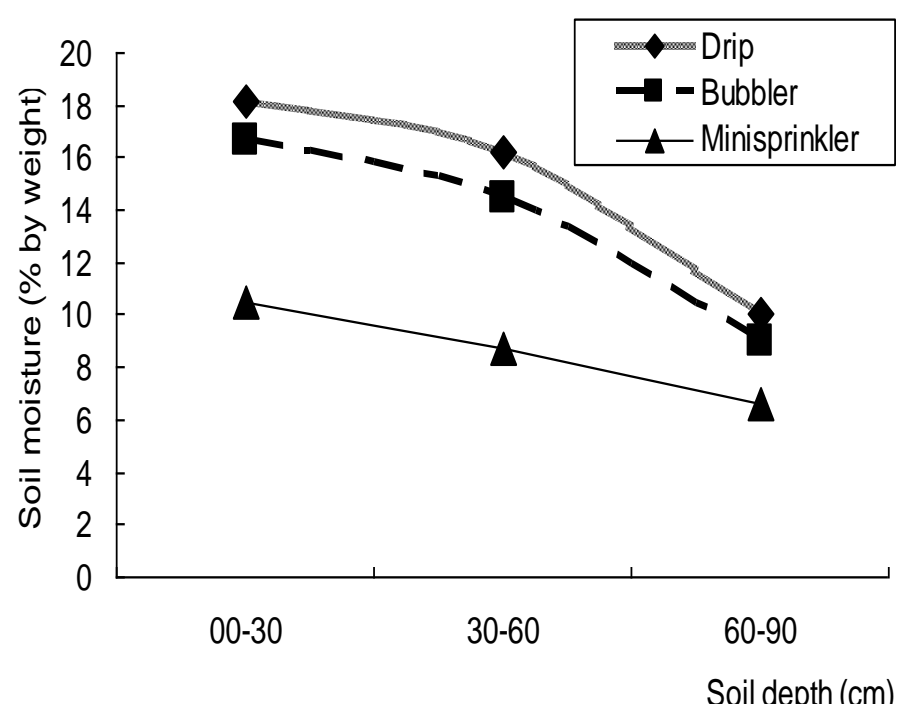

Figure (6): The effect of different MIS on soil moisture.

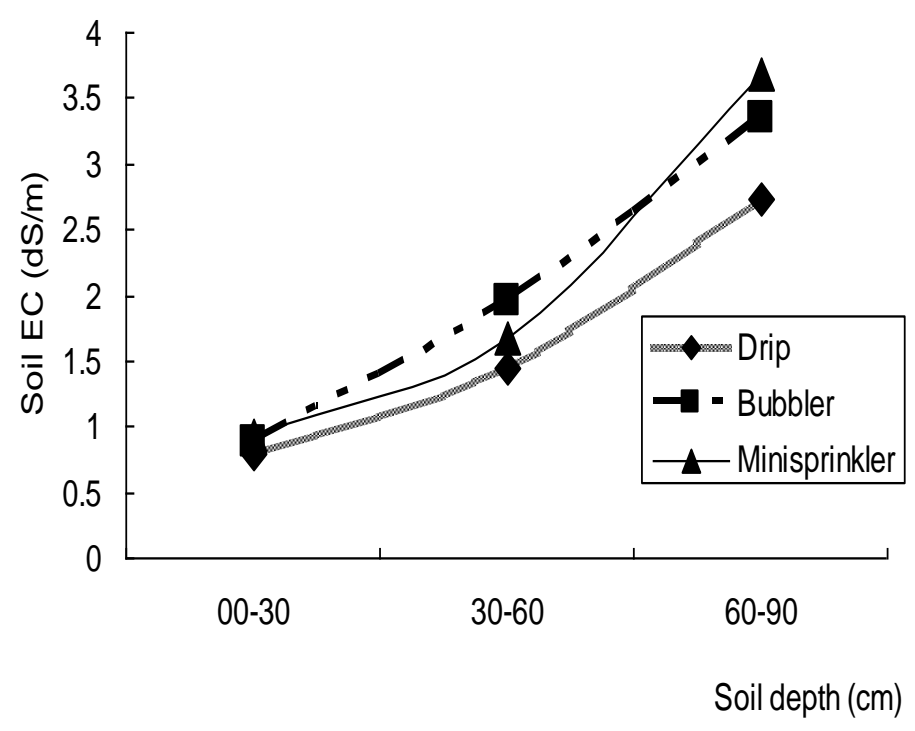

Figure (7): The effect of different MIS on soil salinity.

\section{4-5 Statistical Analysis}

Statistical analysis using the $\mathrm{F}$ test revealed a significant difference in each individual crop parameter by using trickle compared with bubbler and mini-sprinkler irrigation system. 


\section{CONCLUSION}

When using different MIS irrigation systems (trickle, bubbler and minisprinkler) which apply different application irrigation methods the trickle irrigation systems could be considered as appropriate to maintain the best morphological characters for olive trees, good water uniform distribution, sufficient available moisture, acceptable soil salinity levels in the trees root zone, high yield and high yield efficiency. The application of irrigation water through trickle irrigation appears to be effective in minimizing irrigation water losses which in turn leads to an increase in yield efficiency. The water distributor's placement is the key factor in having good water uniformity in the olive trees root.

However, more intensive research is still needed to support such results in this field and some factors must be carefully under taken such as: the effect of using trickle irrigation after a long period, i.e. 7 years on the yield and the soil compared with the mini-sprinkler and bubbler; the effect of using self compensating emitters; the trickle placement i.e. in one or in two lines.

\section{REFERENCES}

\section{Assouline, S.; S. Cohen; D. Meerbach; T. Harodi and M. Rosner} (2002). Micro-drip irrigation of field crops effect on yield, water uptake, and drainage in Sweet Corn. Soil Science Society of America Journal 66:228-235.

Abd El Aziz, R.A. (1998). Effect of some drip irrigation treatments on growth yield and fruit quality in Valencia orange trees under conditions of newly reclaimed land. M.Sc. Thesis, Fac of Agric. Zagazig, Univ., Egypt.

Abd El Samed, G.A. (1995). Effect of irrigation regimes on growth, yield, and water use of olive trees ph. D. Thesis, Fac. of Agric., Fayoum, Cairo, unit Egypt.

Al Khateeb, A.F.M. (1996). The influence of some growth regulators, mineral nutrients on growth and drought resistance of some fig varieties. ph.D. Thesis, Fac. of Agric. Moshtohor, Zagazig, Univ., Egypt.

APHA, American Public Health Association (1989). Standard methods for examination water and wastewater. Washington DC, 17th ed.

Bos, M. G.; D. H. Murray-Rust; D. J. Merrey; H. G. Johnson and W. 
B. Snellen (1994). Methodologies for assessing performance of irrigation and drainage management. Irrigation and Drainage Systems $7: 231-261$.

Bucks, D.A. and S. Davis; (1986). Chapter 1 in trickle irrigation for crop production. Edited by F. S.

Bohm, W (1979) Methods of studying root systems. Ecological studies 33, Springer, Berlin .pp 50-89.

Bos, M. G. and J. Nugteren; (1974). On irrigation efficiencies. International Institute for Land Reclamation and Improvement (ILRI) Publication 19, Wageningen. Revised 1990.

Charles, M. B.; B. Isbell and Lisa Burt; (2005). Long-term salinity buildup on Drip/Micro irrigated trees in California. The Irrigation Association Technical Conference, San Diego, CA. Nov. 18.

Clinton, C. S.; E. B. G. Feibert; A. B. Pereira and Cedric A. Shock; (2004), Automatic collection, radio transmission, and use of soil water data . Mal information for sustainable agriculture, Malheur Experiment Station.

El Khawaga, A.S. (2007). Improving growth and productivity of Manzanillo olive trees with foliar application of some nutrients and girdling under sandy soil. Journal of Applied Sciences Research, 3(9): 818-822.

Emtithal, H.; S. Sanaa; Laz and E.G. Ibrahim;(2002). Yield efficiency, mineral nutrients content and salt distribution in rooting zone of figs trees under different irrigation systems and water quantity in new reclaimed sandy soil. Egypt. J. Appl. Sci., 17 (10): 700-421.

Goda, A. M. G.; (1998). Studies on sensitivity of some olive varieties to drought. M. Sc. Thesis, Fac. of Agric., Fayoum, Cairo. Univ., Egypt.

Ghobrial, S.K.; (1987). Physiological studies on the growth and yield of grape (Vitis vinifera) under the drip irrigation. Ph. D. Thesis, Fac. of Agric., Cairo, Univ., Egypt.

Garcia, I;(1978). Soil water laboratory manual. Dept. Agr and chemical engineering. Colorado State Univ., Fort Collins, Colorado. U.S.A.

Goldberg, S.D.; B. Gornat and Y. Bar; (1971). The distribution of roots, water and minerals as a result of trickle irrigation. J. Amer. Soc. Hort. Sci. 96 (5): 645-648. 
Goldbery, S.D. and M. Shmuli; (1970). Drip irrigation, a method used under arid and desert conditions of high water and soil salinity. Amer. Aoc. of Agric. Eng. 13: 38-41.

Hassan, M.A; (2002). Studies on the irrigation of olive trees grown in new reclaimed soils. Ph. D. thesis, Fac. of. Agric., Zagazig. Univ., Egypt.

Hendrick, R.; and K. Pregitzer; (1996). Temporal and depth related patterns of fine root dynamics in northern hardwood forests, J. Ecol., 84, 167-176.

Ibrahim, E.G.; (1993). Studies on irrigation of banana. Ph. D. Thesis, Fac. of Agric., Zagazig, Univ., Egypt.

Ibrahim, M.N.; M. A. Gouda and M.H. EL Manse; (1988). Effect of soil and management practices on water use efficiency and yield of broad bean and water melon in sandy soils. Egypt. J. Appl. Sci., 3: 170-180.

Israelsen, O.W. and V.E. Hansen, (1962). Irrigation principles and practices. 3rd Ed. John Willey and Sons. New York, U.S.A.

Laz, S.I.; A.H. EL Sherif and S.A. Sari EL Deen; (1999). Studies on the susceptibility of some olive cultivars to drought. Zagazig J. Agric. Res. Vol. 26: P. 1707-1729.

Lynch, J. (1995). Root architecture and plant productivity, Plant Physiology. 109:7-13.

MAPA, (2004). Anuario Estadi'stico. Ministerio de Agricultura, Pesca y Alimentación, Madrid.

Moriana, A. and E. Fereres; (2002). Plant indicators for scheduling irrigation for young olive trees. Irrig. Sci. 21, 83-90.

Michelakis, N.; E. Vougioucalou and G. Clapaki. (1993). Water use, wetted soil volume, root distribution and yield of avocado under drip irrigation. Agri. Water Management. 24:119-131.

Ma-CIsaac, S.A.; V.K. Sawhney and Y. Pohorecky, (1989). Regulation of lateral root formation in lettuce (Lactuca sativa) seedling roots: Interacting effects of anaphthalen acid and kinetin. Physiology plant. 77:287-293.

Patumi, M.; P. Giorgio and G. Serentino; (2000). Yield and quality intensively trained trees of three cultivars of olive under different 
irrigation regimes. Journal of Horticultural Science and Biotechnology, 74 (6): $729-737$.

Peterson, R.G. and L.D. Calvin; (1965). Sampling JNCA Blac. (ed) Methods of soil analysis. Am. Soc. Agron. 9 Moadison WI. Agron., 9 : $54-71$.

Rao, P. S.; (1993). Review of selected literature on indicators of irrigation performance. IIMI Research Paper No. 13. Colombo, Sri Lanka: International Irrigation Management Institute.

Rugiero, C.; (1991). Effect of water regime on apricot in Vesuvian area. Acta Hort., 293 : $443-449$.

Sorensen, R. B.; F. S. Wright and C. L. Butts; (2001). Subsurface drip irrigation system designed for research in row crop rotations. Applied Engineering in Agriculture. Vol. 17(2): 171-176.

Stevens, R.M., and T. Douglas; (1994). Distribution of grape vine roots and salt under drip and full-ground cover micro-jet irrigation systems. Irrig. Sci. 15:147-152.

San-Antonio, D.; (1982). Production and turnover of fine roots of mature Douglas-fir in relation to site. Ph.D. Thesis, Oregon State University, Corvallis, Oregon 1982.

Snedecor, G.W. and W. G. Cochran; (1980). Statistical methods, 7th Iowa Univ., Press, Amer., Iowa, U.S.A.

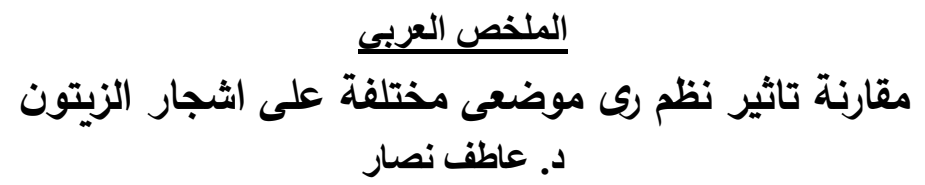

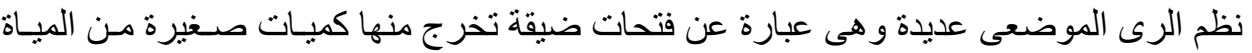

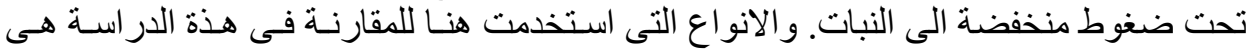
الرى بالتنقيط و النافورى و الرشاشات التشئ الصغيرة.

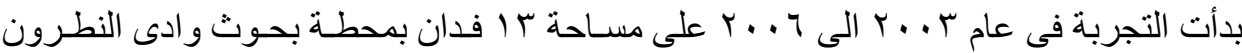

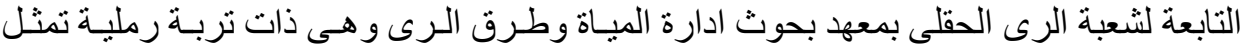

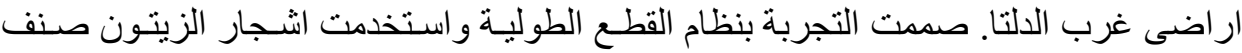

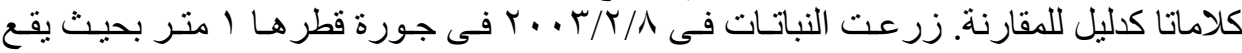

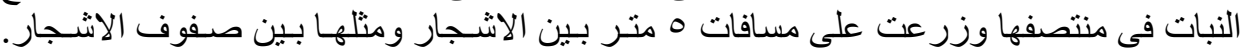

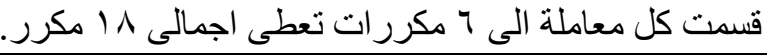

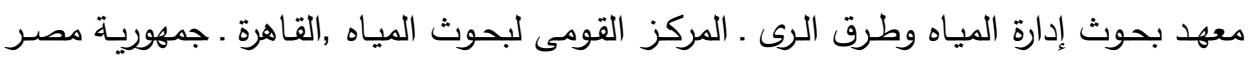
العربية 


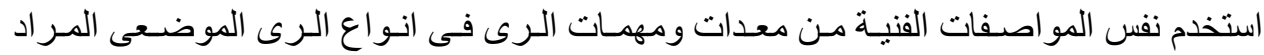

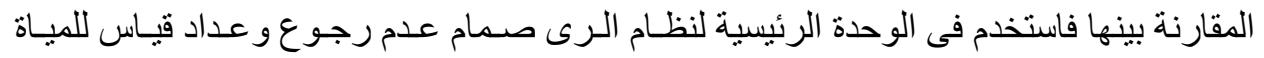

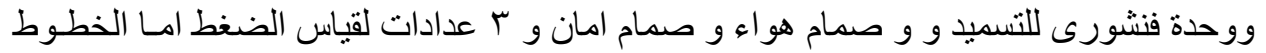

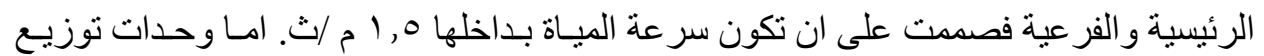

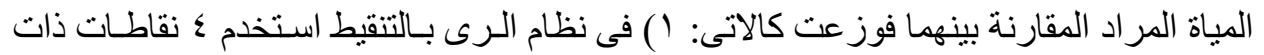

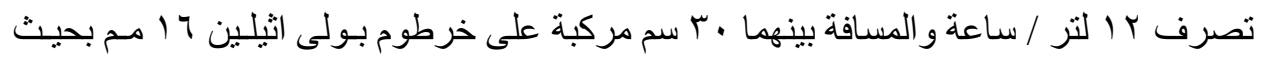

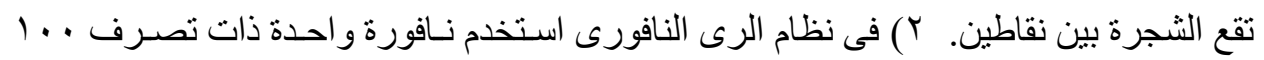

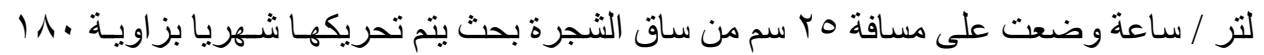

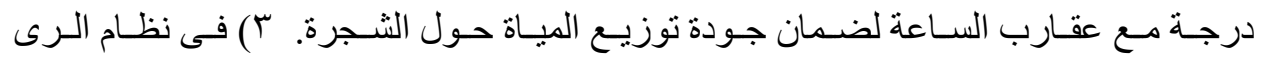

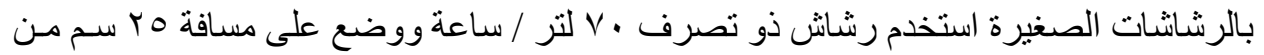

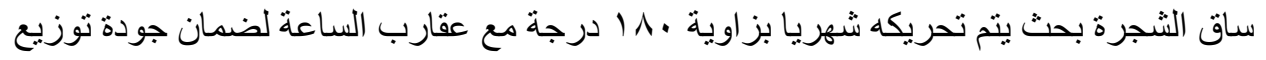
المياة حول الثجرة.

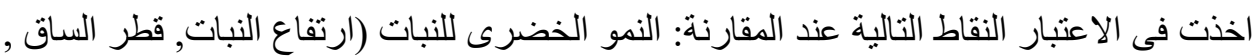

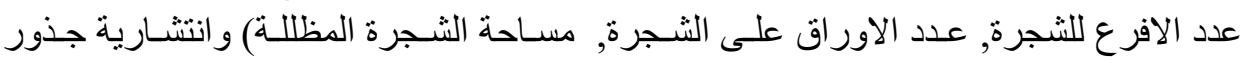

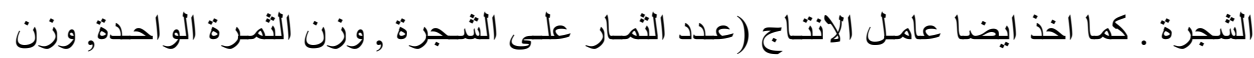
الثمار على الثجرة ووزن الانتاج الكلى على وحدة المساحة).

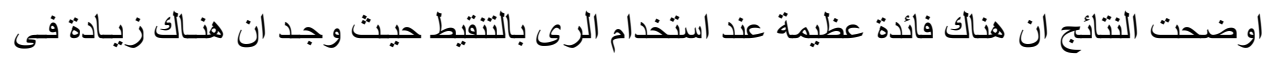

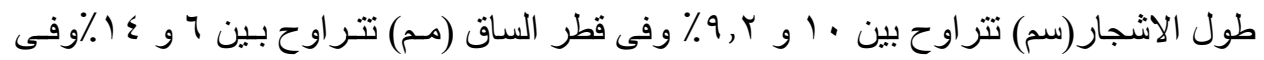

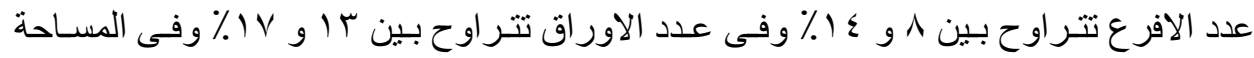

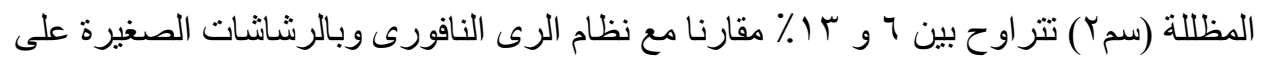

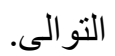

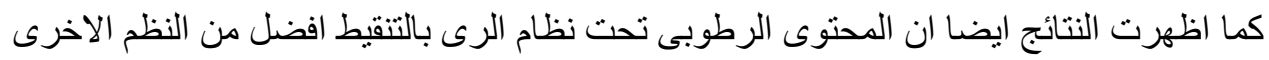

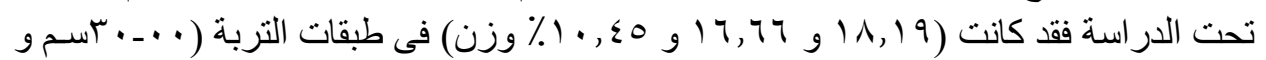

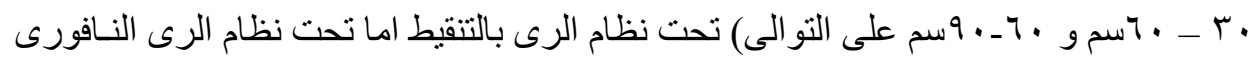

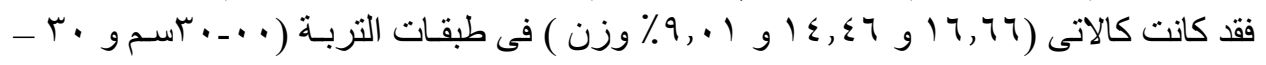

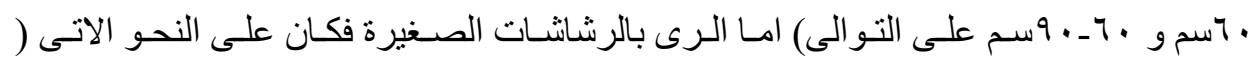

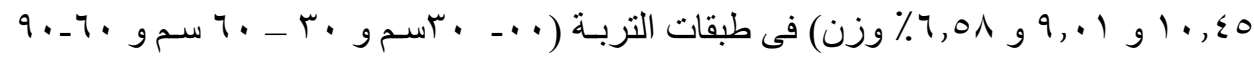

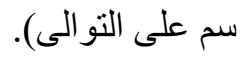

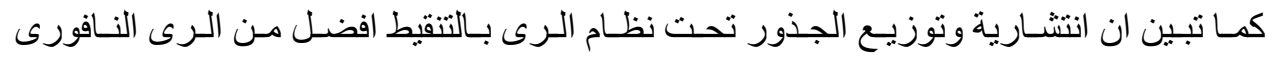

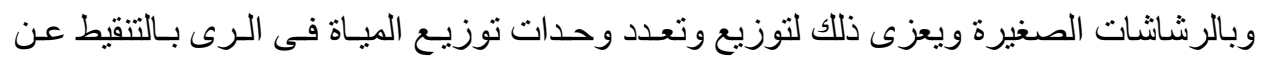
النو عين الاخرين تحت الدر اسة. 


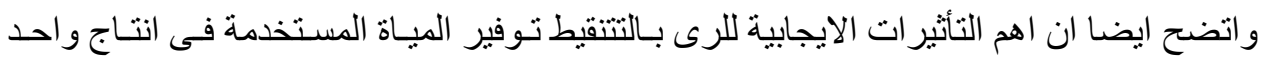

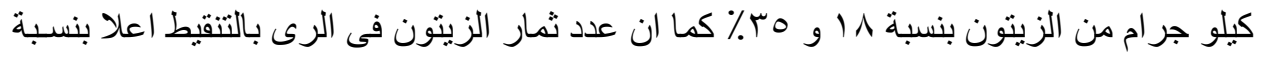

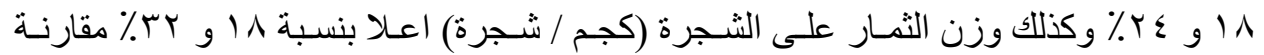

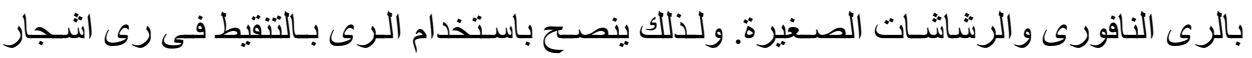

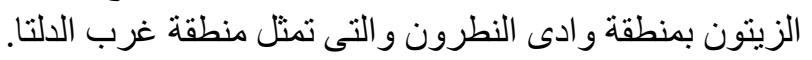

